\title{
Identification of the formate dehydrogenases and genetic determinants of formate-dependent nitrite reduction by Escherichia coli K12
}

\author{
A. Darwin, P. Tormay, $\dagger$ L. Page, L. Griffiths and J. Cole* \\ School of Biochemistry, University of Birmingham, Birmingham B15 2TT, UK
}

(Received 25 January 1993; accepted 29 March 1993)

\begin{abstract}
The formate dehydrogenases of Escherichia coli involved in electron transfer from formate to nitrite (Nrf activity: nitrite reduction by formate) have been identified. No previously undescribed selenoprotein was detected in bacteria grown under conditions optimal for the expression of Nrf activity. The Nrf activities of single mutants defective in either FdhN or FdhH were between 50 and $60 \%$ that of the parental strain. A double mutant defective in both FdhN and FdhH retained less than $10 \%$ of the activity of the $\mathrm{FdhN}^{+} \mathrm{FdhH}^{+}$strain. No Nrf activity was detected in a triple mutant defective in FdhN, FdhH and FdhO or in the selC strain. It is concluded that all three of the known formate dehydrogenases of $E$. coli can contribute to the transfer of electrons from formate to the Nrf pathway. Mutants defective in Nrf activity and cytochrome $c_{552}$ synthesis were isolated by insertion mutagenesis or identified amongst strains received from the $E$. coli Genetic Stock Center. The mutations were located in at least three regions of the chromosome, including the 92 to 94 minute region which includes $f d h F$, the gene encoding FdhH required for formate hydrogenlyase activity. Fine structure mapping by P1 transduction established that the $n r f$ mutations in the $f d h F$ region were due to defects in three separable loci, all of which were independent of but close to $f d h F$. Clones were isolated from a cosmid library that complemented a deletion extending from $f d h F$ into a region essential for Nrf activity. From these clones, plasmids were isolated that complemented only some of the Nrf ' mutations in the 92 to 94 minute region, confirming the presence of different operons essential for Nrf activity and cytochrome $c_{552}$ synthesis in this region. Suggested reasons for this genetic complexity include the need for proteins involved in electron transfer from the various formate dehydrogenases to cytochrome $c_{552}$, for the attachment of the haem group to the apocytochrome and for cytochrome $c_{552}$ export into the periplasm.
\end{abstract}

\section{Introduction}

Anaerobic cultures of many enteric bacteria, including Escherichia coli, can use either formate or NADH to reduce nitrite rapidly to ammonia (Abou-Jaoudé et al., $1979 a, b$; Cole, 1988; Page et al., 1990). The two pathways are biochemically and genetically independent (Pope \& Cole, 1982). Although the structures, synthesis and regulation of the components of the NADHdependent pathway have been thoroughly characterized both biochemically and genetically (Cole, 1988; Harborne et al., 1992), far less is known about the less active, formate-dependent pathway (Nrf: nitrite reduction by formate).

Fujita \& Sato $(1966 a, b ; 1967)$ were the first to associate cytochrome $c_{552}$ with nitrite reduction to

*Author for correspondence. Tel. 021414 5440; fax 0214143982.

$\nmid$ Present address: Lehrstuhl für Mikrobiologie, Universität München, Maria-Ward-Strasse 5a, München, Germany. ammonia by $E$. coli. Abou-Jaoudé et al. (1979a,b) established that formate was the electron donor for a membrane-associated electron transfer chain to nitrite and Motteram et al. (1981) demonstrated that a membrane potential was generated during Nrf activity. Twenty years after its first published purification and characterization by Fujita (1966), Kajie \& Anraku (1986) repurified cytochrome $c_{552}$ and reported it to be a $69 \mathrm{kDa}$ polypeptide with six associated haem groups. The aims of the experiments described here were to identify the dehydrogenases which transfer electrons from formate to the cytochrome and to locate $E$. coli chromosomal genes essential for Nrf activity.

\section{Methods}

Strains used and their source. All strains used in this work are listed in Table 1 together with details of their source or method of construction.

Media and growth conditions. To determine rates of nitrite reduction by formate or glucose, bacteria were grown in unshaken 1.0 or 2.0 litre conical flasks filled with the minimal salts (MS) medium described by 
Table 1. Strains used and their source

\begin{tabular}{|c|c|c|}
\hline Strain & Relevant genotype or phenotype & Reference or source \\
\hline CGSC 4260 & JC $1553 \mathrm{~F}^{\prime} 112$ & \\
\hline CGSC 4312 & HFr P4X met $B$ & \\
\hline CGSC 4432 & purA rpsL & E. coli Genetic Stock Center, Yale Univ., New Haven, CT, \\
\hline CGSC 4517 & pyrB & USA \\
\hline CGSC 4926 & HFr Cavalli metB1 melA7 & \\
\hline CGSC 10235 & $\mathrm{HFrH}$ & \\
\hline FM460 & MC4100 AselC: : $\operatorname{Kan}^{\mathrm{R}}$ & Rossmann et al. (1991) \\
\hline FM932 & $\Delta f d h F$ mel: $: \operatorname{Tn} 10$ & Pecher et al. (1983) \\
\hline JCB351 to JCB379 & $\Delta$ nirB $n r f-351$ to 379 & $\begin{array}{l}\text { This work: } \text { Nrf }^{-} \text {temperature-stabilized Mudl insertions in } \\
\text { JCB387 }\end{array}$ \\
\hline JCB387 & E. coli RV $\Delta$ nir $B$ & $\begin{array}{l}\text { Transduce JCB303 (Griffiths \& Cole, 1987) to } \mathrm{Nar}^{+} \text {with } \\
\text { P1 from E. coli RV }\end{array}$ \\
\hline JCB601 to JCB606 & $\Delta$ nirB $n r f-601$ to 606 & This work: Nrf $\lambda$ placMu insertion mutants of JCB387 \\
\hline JCB3406 & M9 $\Delta n i r B n r f^{+}$ & Transduce M9cysG to Cys ${ }^{+}$with JCB387-P1 \\
\hline JCB3513 & CGSC $4432 n r f-351$ & Transduce CGSC4432 to $\mathrm{Amp}^{\mathrm{R}}$ with CGSC4432-P1 \\
\hline JCB3876 & $\mathrm{JCB} 387 f d h F$ & Transduce JCB387 to Amp ${ }^{R}$ with FM909-P1 \\
\hline JCB3877 & $\mathrm{JCB} 387 \mathrm{fdn} G$ & Transduce JCB387 to Kan ${ }^{\mathrm{R}}$ with VJS1224-P1 \\
\hline JCB3878 & $\mathrm{JCB} 387 \Delta(n r f-f d h F)$ & Transduce JCB387 to $\mathrm{Tet}^{\mathrm{R}}$ with FM932-P1 \\
\hline JCB3880 & $\mathrm{JCB} 387 f d n G f d h F\left(\mathrm{Amp}^{\mathrm{R}}\right)$ & $\begin{array}{l}\text { Transduce JCB } 3877 \text { to } A m p^{R} \text { with } \mathrm{P} 1 \text { from a temperature- } \\
\text { stabilized derivative of } M 9\end{array}$ \\
\hline JCB3881 & JCB387 $\Delta$ sel: : $\operatorname{Kan}^{\mathrm{R}}$ & Transduce JCB387 to $\mathrm{Kan}^{\mathrm{R}}$ with FM460-P1 \\
\hline JCB3882 & JCB387 $f d n G f d h F f d o$ & \\
\hline JCB6023 & CGSC 4432 narL: : Tn10 nrf-602 & \\
\hline JCB6033 & CGSC 4432 narL: : Tn10 nrf-603 & Transduce CGSC 4432 to $\mathrm{Tet}^{\mathrm{R}}$ with $5278-\mathrm{P} 1$; then to $\mathrm{Kan}^{\mathrm{R}}$ \\
\hline JCB6043 & CGSC 4432 narL: : Tn10 nrf-604 & with JCB602-JCB606-P1 \\
\hline JCB 6053 & CGSC 4432 narL: : $\operatorname{Tn} 10$ nrf-605 & \\
\hline JCB6063 & CGSC 4432 narL: : $\operatorname{Tn} 10$ nrf-606 & \\
\hline JCB6061 & $\mathrm{JCB} 387 \Delta(n r f-f d h F)$ mel: : $\mathrm{Tn} 10$ & Transduce JCB387 with FM932-P1 \\
\hline JCB6069 & JCB606 mel: :Tn10 & Transduce JCB606 to $\mathrm{Tet}^{\mathrm{R}}$ with FM932-P1 \\
\hline JM712 & pro his trp $\Delta l a c$ & M. Jones-Mortimer \\
\hline MA50 & fdo: : MudA' $\operatorname{Kan}^{\mathbf{R}}$ & M.-A. Mandrand (unpublished) \\
\hline M9 & $f d h F$ & Pecher et al. (1983) \\
\hline M9cysG & & Transduce $\mathrm{M} 9$ to $\mathrm{Kan}^{\mathrm{R}}$ with $\mathrm{JCB} 322-\mathrm{P} 1$ \\
\hline MC4100 & & Casadaban \& Cohen (1979) \\
\hline $\mathrm{MC} 4100$ cysG & & $\begin{array}{l}\text { Transduce MC4100 to Kan }{ }^{R} \text { with JCB322-P1 (Griffiths \& } \\
\text { Cole, 1987) }\end{array}$ \\
\hline VJS1224 & $f d n G:$ :MudII1734 $\left(\mathrm{Kan}^{\mathrm{R}}\right)$ & Berg \& Stewart (1990) \\
\hline
\end{tabular}

Pope \& Cole (1982) supplemented with half-strength nutrient broth and $10 \mu \mathrm{M}$-selenate and -molybdate (Page et al., 1990). The main carbon and energy source was either $0.4 \%(\mathrm{w} / \mathrm{v})$ glucose or $0.4 \%(\mathrm{w} / \mathrm{v})$ glycerol $+40 \mathrm{~mm}$-fumarate, as noted.

Inocula for anaerobic batch cultures were grown aerobically to late exponential phase in $20 \mathrm{ml}$ of Lennox broth (LB). Stock cultures were maintained at $-20{ }^{\circ} \mathrm{C}$ in $\mathrm{LB}$ supplemented with $20 \%$ (v/v) glycerol. Working cultures were maintained for up to 8 weeks on nutrient or Lennox agar at $4{ }^{\circ} \mathrm{C}$.

Insertion mutagenesis. E. coli strain JCB387 was mutagenized with MudlAplac as described previously (Griffiths \& Cole, 1987). Ampicillin-resistant colonies were purified on nutrient agar (NA) supplemented with $50 \mu \mathrm{g}$ ampicillin (Amp) $\mathrm{ml}^{-1}$ and tested for $\mathrm{Nrf}$ activity as described below. Mutagenesis of an overnight culture of JCB387 which had been grown in tryptone broth with $\lambda$ placMu9 was essentially as described by Bremer et al. (1984) except that bacteria were suspended in $10 \mathrm{mM}-\mathrm{MgCl}_{2}$ before mutagenesis. In each experiment, two different infection mixes were set up: one contained $4 \mu \mathrm{l}$ of $\lambda$ plac Mu9 and $40 \mu \mathrm{l}$ of helper $\lambda$ pMu507 (Bremer et al., 1985); 10 times as much of each phage were added to the second infection mix. Each transduction mixture was diluted to $10^{-4}, 10^{-5}$ and $10^{-6}$ and $100 \mu \mathrm{l}$ aliquots were plated onto NA + Amp.
Rates of nitrite reduction by washed bacteria and cytochrome $c_{552}$ concentrations. The rates of nitrite reduction by formate (Nrf activity) or glucose were determined exactly as described by Pope \& Cole (1984). Cytochrome $c_{552}$ concentrations in either the high speed supernatant fraction from bacteria broken in the French press (Pope \& Cole, 1984) or from the periplasm fraction released by incubating bacterial suspensions with chloroform (Ames et al., 1984) were determined spectroscopically as described by Pope \& Cole (1984). Control experiments revealed that not all of the cytochrome $c_{552}$ was released quantitatively by the chloroform procedure, but as the ratio of cytochrome released to total protein were almost identical in both types of preparation, the two methods were used interchangeably. The two types of preparation are distinguished in the Results section by referring to them as soluble proteins (released by the French press) and periplasmic proteins (released by chloroform treatment).

Determination of phenotypes of $\mathrm{Nrf}^{-}$mutants, exconjugants and transductants. Recombinants from conjugation or transduction experiments were purified by replating them onto the original selective agar and screened for unselected markers. Formate hydrogenlyase activity $\left(\mathrm{Fhl}^{+}\right)$was detected by growing bacteria overnight in $5 \mathrm{ml}$ of $\mathrm{LB}+0.8 \%(\mathrm{w} / \mathrm{v})$ glucose in narrow test-tubes containing an inverted Durham tube. Strains that were $\mathrm{Fhl}^{+}$(and therefore $f d h F^{+}$) 
accumulated $\mathrm{H}_{2}$ in the Durham tube. Mutants defective in the fnr gene failed to form colonies during anaerobic growth on minimal agar with $0.4 \%(w / v)$ glycerol and $40 \mathrm{~mm}$-fumarate as the carbon and energy source. To score the nitrate reductase (Nar) phenotype, bacteria were grown anaerobically in LB supplemented with $0.4 \%(\mathrm{w} / \mathrm{v})$ glucose and $20 \mathrm{~mm}$-nitrate, sedimented by centrifugation, resuspended in $50 \mathrm{~mm}$ phosphate, $\mathrm{pH} 7 \cdot 4$, to a density of approximately $1 \mathrm{mg}^{\mathrm{m} y} \mathrm{wt} \mathrm{ml} \mathrm{m}^{-1}$ and incubated with $40 \mathrm{~mm}$-formate and $20 \mathrm{~mm}$-nitrate. In contrast to $\mathrm{Nar}^{+}$ strains, which had accumulated nitrite within $2 \mathrm{~min}$, Nar- strains were negative (or only weakly positive) for nitrite after $10 \mathrm{~min}$ at $30^{\circ} \mathrm{C}$. Chlorate-resistant $\left(\mathrm{Mol}^{-}\right.$; formerly $\mathrm{Chl}^{\mathrm{R}}$ ) strains formed colonies during overnight anaerobic growth at $37^{\circ} \mathrm{C}$ on LB supplemented with $0.4 \%(\mathrm{w} / \mathrm{v})$ glucose and $10 \mathrm{~mm}$-potassium chlorate. $\mathrm{Mel}^{+}$strains formed colonies on minimal agar $+0.2 \%(w / v)$ melibiose after $2 \mathrm{~d}$ at $30^{\circ} \mathrm{C}$.

Many attempts to devise a selective medium for $\mathrm{Nrf}^{+}$strains that were defective for the more active Nir pathway were unsuccessful. The Nrf phenotype was therefore scored by inoculating a test-tube containing $1 \mathrm{ml}$ of $\mathrm{LB}+$ glucose $+1 \mathrm{mM}$-nitrite with the strain to be tested. After overnight growth without aeration, $3 \mathrm{ml}$ of MS + glucose was added. After a further $3 \mathrm{~h}$ at $37^{\circ} \mathrm{C}$ without aeration (or when visible growth had occurred), $50 \mu \mathrm{l}$ samples of an isogenic $\mathrm{Nrf}^{+}$control culture were spot-tested for nitrite. When no nitrite was present in the

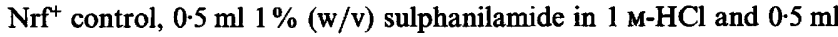
$0.02 \% \mathrm{~N}$-1-naphthylethylenediamine dihydrochloride were added to the remaining cultures. The formation of an intense pink colour after $30 \mathrm{~s}$ indicated the presence of nitrite and a $\mathrm{Nrf}^{-}$phenotype. The original $\mathrm{Nrf}^{-}$mutants were originally detected by a slightly modified procedure in which $1 \mathrm{ml}$ of LB overnight cultures of bacteria from individual colonies were supplemented with $3 \mathrm{ml}$ of $\mathrm{MS}+$ glucose and 1 mu-nitrite.

Although the Nrf pathway is partially repressed during growth in $\mathrm{LB}+$ glucose and derepressed in MS supplemented with glycerol + fumarate, attempts to improve the discrimination between $\mathrm{Nrf}^{+}$and $\mathrm{Nrf}^{-}$strains under the latter conditions were only partially successful because many $\mathrm{Nrf}^{+}$strains grow poorly and are therefore falsely scored as $\mathrm{Nrf}^{-}$. The Nir phenotype was determined in a similar procedure except that individual colonies were grown aerobically overnight in $1 \mathrm{ml}$ of LB and supplemented with $3 \mathrm{ml}$ of $\mathrm{MS}+0.4 \%$ glucose and 2.5 mM-nitrite.

Recombinant DNA techniques. Small-scale DNA preparations, restriction digests, agarose and polyacrylamide gel electrophoresis, the isolation of DNA fragments, the preparation and transformation of competent bacteria and other routine DNA manipulations were as described by Maniatis et al. (1982). Chromosomal DNA for cloning into the EMBL cos 4 vector was prepared from a $20 \mathrm{ml}$ overnight LB culture as described by Chesney et al. (1979) and size-fractionated by caesium chloride gradient centrifugation. High $M_{\mathrm{r}}$ DNA was partially digested with Sau3A to generate fragments larger than 35 kilobases (kb), as judged by electrophoresis on a $0.2 \%$ agarose gel. These fragments were size-fractionated by density gradient centrifugation; fractions with fragments in the range 35 to $48 \mathrm{~kb}$, as judged by agarose gel electrophoresis, were dephosphorylated with calf alkaline phosphatase, extracted with phenol and precipitated with ethanol. The cos4 vector was restricted to completion with $P v u I I$, dephosphorylated, extracted twice with phenol/chloroform, ethanol precipitated and restricted with BamHI to inactivate the tetracycline resistance gene and generate the two cosmid arms. After further phenol extraction and ethanol precipitation, $1.5 \mu \mathrm{g}$ of the cosmid arms DNA was ligated with $3 \mu \mathrm{g}$ of the purified, size-fractionated chromosomal DNA. After $16 \mathrm{~h}$ at $14^{\circ} \mathrm{C}, 4 \mu \mathrm{l}$ aliquots of the ligation mixture were packaged according to the Stratagene GIGAPACK Gold packaging procedure. The cosmid library was transformed into competent JCB3878 and Amp ${ }^{\mathrm{R}}$ transformants were selected on nutrient agar $+50 \mu \mathrm{g} \mathrm{Amp} \mathrm{ml}^{-1}$.
Sub-cloning of nrf DNA into a low copy number plasmid vector. DNA prepared from two of the cosmids that transformed JCB3878 to $\mathrm{Nrf}^{+}$ was partially digested with Sau3A and ligated to pLG339 DNA (Stoker et al., 1982) that had been restricted with BamHI and dephosphorylated. Competent JCB3878 bacteria were transformed to kanamycin resistance $\left(\mathrm{Kan}^{\mathrm{R}}\right)$ with the ligation mix. The 200 transformants were screened for $\mathrm{Nrf}^{+}$clones; plasmid DNA was isolated from six of the $\mathrm{Nrf}^{+}$clones and the partial restriction maps of three of the smallest clones were determined. The sub-clone with the smallest DNA fragment, pLD5, that consistently transformed JCB3878 to $\mathrm{Nrf}^{+}$, was used for the majority of the subsequent experiments.

The only selectable marker on pLD5 was $\mathrm{Kan}^{\mathrm{R}}$. To generate a comparable plasmid suitable for transformation into the $\mathrm{Kan}^{\mathrm{R}} \mathrm{Nrf}^{-}$ mutants, the $9 \mathrm{~kb} \mathrm{EcoRI/SalI} \mathrm{fragment} \mathrm{from} \mathrm{pLD5,} \mathrm{which} \mathrm{includes} \mathrm{all}$ of the E. coli chromosomal DNA and about 300 bases of the tet gene from pLG339, was purified from an agarose gel and ligated into the purified $3.7 \mathrm{~kb}$ Eco RI/SalI fragment of pBR322. Competent JCB3878 was transformed with the ligation mix and $A m p^{R}$ transformants were selected on Lennox agar $+50 \mu \mathrm{g} \mathrm{Amp} \mathrm{ml}^{-1}$.

Labelling of proteins with ${ }^{75}$ selenium. Selenate was omitted from media used for these experiments. Bacteria were first cultured without aeration in $1 \mathrm{ml}$ of either MS, glycerol and fumarate or in LB $+0.4 \%$ glucose, both of which were also supplemented with $0.25 \mu \mathrm{M}$-sodium selenite. Some cultures also contained either $20 \mathrm{mM}$-nitrate or $2.5 \mathrm{mM}$ nitrite. From these inocula, $10 \mu \mathrm{l}$ of the LB cultures or $200 \mu \mathrm{l}$ of the MS cultures were transferred to two test-tubes containing $3 \mathrm{ml}$ of identical medium. One culture of each type was supplemented with $0.25 \mu \mathrm{M}$ unlabelled selenite; to the other was added $0.25 \mu \mathrm{M}\left[{ }^{75}\right.$ Se]selenite

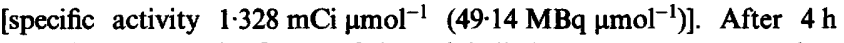
growth at $37^{\circ} \mathrm{C}$, the $\mathrm{OD}_{650}$ of the unlabelled culture was measured as an estimate of the density of the ${ }^{75} \mathrm{Se}$-labelled culture. Samples of the latter $(1 \mathrm{ml})$ were pelleted by centrifugation and stored at $-20^{\circ} \mathrm{C}$.

$S D S-P A G E$ and autoradiography. Bacterial pellets were resuspended in sample buffer to a density of $25 \mathrm{mg}$ bacterial mass $\mathrm{ml}^{-1}$, heated to $100^{\circ} \mathrm{C}$ for $10 \mathrm{~min}$, cooled on ice and $20 \mu \mathrm{l}$ samples were immediately loaded onto a $15 \%(\mathrm{w} / \mathrm{v})$ SDS-PAGE gel. After electrophoresis for $17 \mathrm{~h}$ at $70 \mathrm{~V}$, the resolving gel was transferred to Whatmann $3 \mathrm{MM}$ chromatography paper, dried under vacuum at $80^{\circ} \mathrm{C}$ and autoradiographed.

\section{Results}

\section{Transfer of electrons from formate into the Nrf pathway}

Three formate dehydrogenases have been characterized in $E$. coli, each of which is a selenoprotein associated with a separate electron transfer pathway (Sawers $e t$ al., 1991). In previous ${ }^{75} \mathrm{Se}$ labelling experiments, bacteria had been grown in rich media or in the presence of nitrate, conditions in which Nrf activity is at least partially repressed (Cox et al., 1981; Pecher et al., 1985; Leinfelder et al., 1988; Sawers et al., 1991). As it was possible that a fourth selenoprotein specific to the Nrf pathway had been undetected, selenoproteins synthesized during anaerobic growth under conditions optimal for Nrf expression were compared with those in bacteria grown in rich, glucose-containing medium. Strain JCB387 $\left(\mathrm{FdhF}^{+} \mathrm{FdhN}^{+} \mathrm{FdhO}^{+}\right)$was grown anaerobically in the presence of $\left[{ }^{75} \mathrm{Se}\right]$ selenite in both $\mathrm{LB}+$ glucose with or without $20 \mathrm{~mm}$-nitrate and in minimal salts supplemented with glycerol, fumarate and 


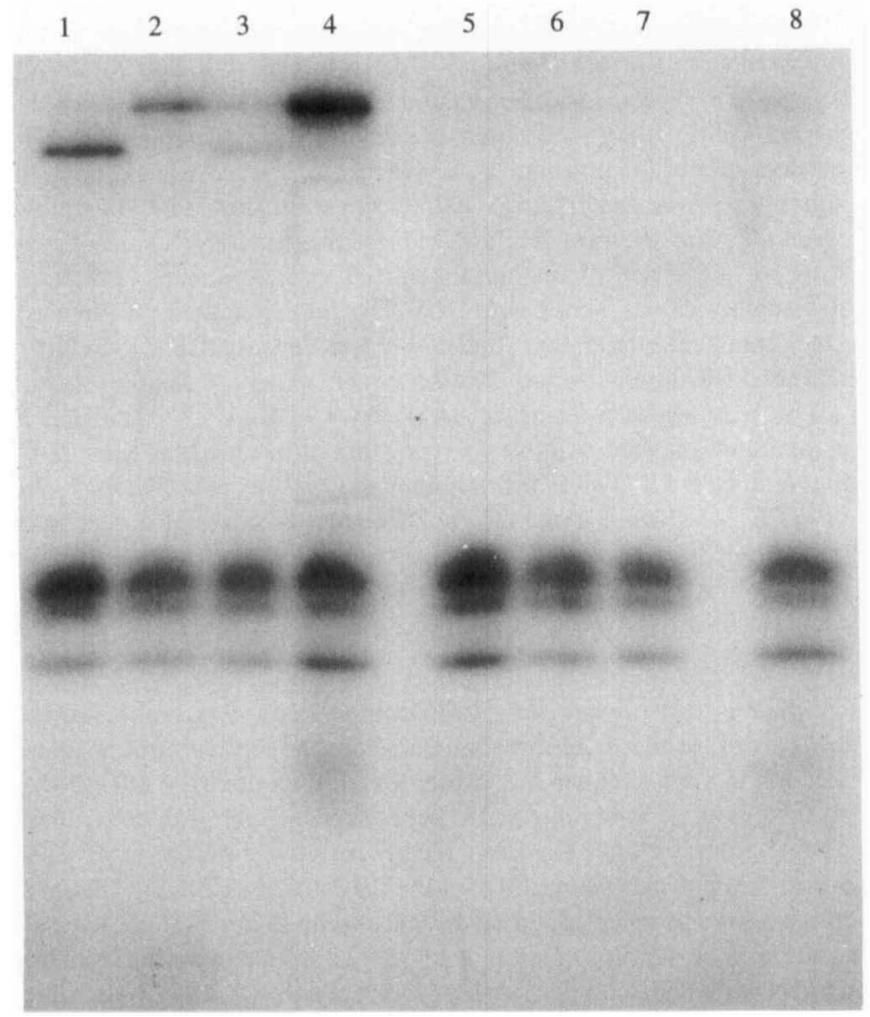

Fig. 1. Selenoproteins synthesized by a double mutant of $E$. coli defective in both of the major formate dehydrogenases and by the parental strain after growth in different media. The $\mathrm{FdhN}^{-} \mathrm{FdhF}^{-}$ mutant, strain JCB3880, and its parental strain JCB387 were grown anaerobically in the presence of $\left[{ }^{75} \mathrm{Se}\right]$ selenite in either Lennox broth (LB) or in minimal medium (MS) with various supplements, as listed. Proteins in $20 \mu \mathrm{l}$ of the cell lysates were separated by SDS-PAGE and selenoproteins were detected by autoradiography. Tracks 1 to 4 , JCB387; tracks 5 to 8 , strain JCB3880. The growth media were LB + glucose (tracks 1 and 5); LB + glucose and 20 mM-nitrate (tracks 2 and 6); MS + 0.4\% (w/v) glycerol +40 mM-fumarate (tracks 3 and 7); $\mathrm{MS}+$ glycerol, fumarate and $2.5 \mathrm{~mm}$-nitrite (tracks 4 and 8 ).

either $2.5 \mathrm{~mm}$-nitrite or $20 \mathrm{~mm}$-nitrate. Radiolabelled proteins were separated by SDS-PAGE and detected by autoradiography (Fig. 1). The $80 \mathrm{kDa}$ product of the $f d h F$ gene was the major selenoprotein detected in bacteria grown in LB + glucose. Synthesis of this polypeptide was repressed by nitrate, but the $110 \mathrm{kDa}$ FdnG selenoprotein was induced (Fig. 1). The $f d n G$ product was also induced during growth in minimal medium supplemented with nitrate, and small quantities of both the FdhF and FdnG polypeptides were detected in bacteria grown in nitrite-supplemented minimal medium.

As FdnN and FdhO are both $110 \mathrm{kDa}$ polypeptides, the poorly expressed FdhO could not be seen in the above experiments. They were therefore repeated using a double mutant, JCB3880, which is defective in both the $f d h F$ and $f d n G$ genes. No clear selenoprotein band was detected in this double mutant after growth in $\mathrm{LB}+$ glucose due to the lack of a functional $f d h F$ gene.
The addition of nitrate to LB induced a very low level of expression of the $110 \mathrm{kDa}$ FdhO polypeptide (Fig. 1). The poorly expressed FdhO polypeptide was also the only selenopeptide detected in bacteria grown in minimal medium with glycerol, fumarate and nitrite. These results established that no novel selenoprotein is synthesized when bacteria are grown under conditions optimal for Nrf expression.

\section{Contribution of each of the three known formate dehydrogenases to nitrite reduction by formate}

Isogenic strains lacking one or both of the major nitrite reductases as well as a triple mutant lacking all three enzymes were constructed. The cytochrome content and Nrf activities of these strains were compared with those of the parental strain (Table 2). As these strains grew very poorly in minimal medium with glycerol and fumarate as the main carbon and energy source, bacteria were grown in minimal salts supplemented with $5 \%$ (v/v) LB, glucose and nitrite.

Both of the single mutants were $\mathrm{Nrf}^{+}$, but the rates of nitrite reduction by washed bacteria were significantly lower than that of the parental strain. Only a very low rate was detected in the $\mathrm{FdhF}^{-} \mathrm{FdhN}^{-}$double mutant, and this was undetectable in the triple mutant. Although these data strongly imply that all three formate dehydrogenases can transfer electrons from formate into the Nrf pathway, there was no parallel loss of glucosedependent rates of nitrite reduction (Table 2), indicating that the strains were able to use one or more electron donors other than formate or NADH to reduce nitrite.

A mutant incapable of incorporating selenocysteine into polypeptides was constructed by transducing the $\mathrm{Nir}^{-} \mathrm{Nrf}^{+}$strain JCB387 to selC: : $\mathrm{Kan}^{\mathrm{R}}$ with bacteriophage P1 propagated on strain FM460 (Sawers et al., 1991). The resulting strain, JCB3881, was devoid of formate-dependent nitrite reduction, confirming the original report by Abou-Jaoudé et al. $(1979 b)$ that a selenoprotein is essential for the transfer of electrons from formate to cytochrome $c_{552}$. Similar quantities of cytochrome $c_{552}$ [typically in the range 120 to 200 pmol (mg soluble protein $)^{-1}$ but higher in the triple mutant] were synthesized by all of the strains used in this study (Table 2).

\section{Isolation of mutants defective in formate-dependent nitrite reduction}

Strains defective in Nrf activity were from four sources. The first strains, numbered JCB351 to 379, were generated by insertion mutagenesis of the prototrophic, $\mathrm{Nir}^{-}, E$. coli strain JCB387 by the temperature-sensitive operon fusion phage, Mud1Aplac. Subsequently, further 
Table 2. Contribution of the three different formate dehydrogenases to formate-dependent nitrite reduction

\begin{tabular}{|c|c|c|c|c|}
\hline \multirow[b]{2}{*}{ Strain } & \multirow[b]{2}{*}{ Relevant phenotype } & \multicolumn{2}{|c|}{ Nitrite reduction by:* } & \multirow{2}{*}{$\begin{array}{l}\text { Cytochrome } \\
c_{552} \text { concn } \dagger\end{array}$} \\
\hline & & glucose & formate & \\
\hline JCB387 & $\mathrm{FdhN}^{+} \mathrm{FdhH}^{+} \mathrm{FdhO}^{+}$ & $\begin{array}{l}0.71 \\
0.93\end{array}$ & $\begin{array}{l}1.05 \\
1.02\end{array}$ & $\begin{array}{l}120 \\
176\end{array}$ \\
\hline JCB3876 & $\mathrm{FdhN}^{+} \mathrm{FdhH}^{-} \mathrm{FdhO}^{+}$ & $\begin{array}{l}0.74 \\
0.70\end{array}$ & $\begin{array}{l}0.58 \\
0.44\end{array}$ & $\begin{array}{l}201 \\
128\end{array}$ \\
\hline JCB3877 & $\mathrm{FdhN}^{-} \mathrm{FdhH}^{+} \mathrm{FdhO}^{+}$ & $\begin{array}{l}0.75 \\
0.55\end{array}$ & $\begin{array}{l}0.59 \\
0.45\end{array}$ & $\begin{array}{l}139 \\
120\end{array}$ \\
\hline JCB3880 & $\mathrm{FdhN}^{-} \mathrm{FdhH}^{-} \mathrm{FdhO}^{+}$ & $\begin{array}{l}0.44 \\
0.46\end{array}$ & $\begin{array}{l}0.10 \\
0.12\end{array}$ & $\begin{array}{l}176 \\
360\end{array}$ \\
\hline JCB3881 & $\mathrm{Sel}^{-}\left(\mathrm{FdhN}^{-} \mathrm{FdhH}^{-} \mathrm{FdhO}^{-}\right)$ & $\begin{array}{l}0.66 \\
0.43\end{array}$ & $\begin{array}{l}<0.01 \\
<0.01\end{array}$ & $\begin{array}{l}160 \\
206\end{array}$ \\
\hline JCB3882 & $\mathrm{FdhN}^{-} \mathrm{FdhH}^{-} \mathrm{FdhO}^{-}$ & $\begin{array}{l}0.41 \\
0.40\end{array}$ & $\begin{array}{l}<0.01 \\
<0.01\end{array}$ & $\begin{array}{l}389 \\
642\end{array}$ \\
\hline
\end{tabular}

* Rates of nitrite reduction are expressed as $\mu \mathrm{mol}$ nitrite reduced $\mathrm{h}^{-1}(\mathrm{mg} \text { bacterial dry mass })^{-1}$.

$\dagger$ Cytochrome concentrations are nmol cytochrome $c_{552}$ (g soluble protein) ${ }^{-1}$.

Table 3. Characterization of $\lambda$ placMu insertion mutants of E. coli JCB387 defective in formate-dependent nitrite reduction

Colonies of each insertion mutant were also tested for ability to reduce phenazonium methosulphate or benzyl viologen ( $\mathrm{FdhN}$ or FdhH phenotype, respectively), but the results were too ambiguous for phenotypes to be assigned with any certainty.

\begin{tabular}{|c|c|c|c|c|c|}
\hline Phenotype determined & Group 1 & Group 2 & Group 3 & Group 4 & Group 5 \\
\hline Nrf activity & - & - & - & - & - \\
\hline $\begin{array}{l}\text { Fnr test: growth on } \\
\text { glycerol + fumarate }\end{array}$ & - & + & - & + & + \\
\hline Nitrate reduction & - & + & - & + & + \\
\hline $\begin{array}{l}\text { Formate hydrogenlyase: } \mathrm{H}_{2} \\
\text { production from glucose }\end{array}$ & - & - & - & + & + \\
\hline Chlorate resistance & - & - & + & - & - \\
\hline Cytochrome $c_{552}$ & - & ND & ND & + & - \\
\hline
\end{tabular}

ND, Not determined.

insertion mutants were generated in the same host using the protein fusion phage $\lambda$ plac $\mathrm{Mu} 9$. Attempts to isolate mutants defective in periplasmic proteins using the TnphoA vector (Manoil \& Beckwith, 1985) yielded disappointing results. Although many $\mathrm{Amp}^{\mathrm{R}}$ mutants were isolated, approximately $2 \%$ of which gave blue colonies on $\mathrm{X}-\mathrm{P}$ agar, only one $\mathrm{Nrf}^{-}$mutant was found amongst over 6000 screened. In contrast, the most prolific source of $\mathrm{Nrf}^{-}$strains was the $E$. coli Genetic Stock Center: about half of the auxotrophic strains requested for mapping experiments were subsequently found to be $\mathrm{Nrf}^{-}$and were therefore unsuitable for the purpose for which they were obtained.

Antibiotic-resistant transposon insertion strains were first tested individually for $\mathrm{Nrf}$ activity by growing them in $10 \mathrm{ml}$ of $\mathrm{LB}+$ glucose supplemented with $1.0 \mathrm{mM}-$ nitrite in test-tubes. Cultures which had failed to reduce the nitrite after $6 \mathrm{~h}$ of anaerobic growth were retested twice in the same way and then the Mol, Nar, Fnr and Fhl phenotypes were determined. Over $90 \%$ of the initial $\mathrm{Nrf}^{-}$isolates were also defective for other activities (Table 3). Many were resistant to chlorate during anaerobic growth (due to mutations in a mol gene required for molybdenum cofactor synthesis; Group 3, Table 3), unable to reduce nitrate rapidly (mutants defective in haem or molybdenum cofactor synthesis or in the $f n r$ genes; Groups 1 to 3), or failed to produce $\mathrm{H}_{2}$ gas from glucose due to insertions in $\mathrm{fnr}$ or one of the sel genes (Groups 1 and 3; Table 3). These strains were discarded. Selected $\mathrm{Nrf}^{-}$strains which were apparently wild-type for all of the above activities (Groups 4 and 5, Table 3) were grown in 2 litre anaerobic cultures, harvested, and the rates of glucose- and formatedependent nitrite reduction by washed bacterial suspensions were determined (Table 4). The bacteria were broken in the French press and the concentration of 
Table 4. Glucose- and formate-dependent rates of nitrite reduction and cytochrome $c_{552}$ content of $\lambda$ placmuinduced Nrf mutants unaffected in other aspects of anaerobic metabolism

\begin{tabular}{lccc}
\hline \hline & \multicolumn{2}{c}{ Nitrite reduction by:* } \\
\cline { 2 - 3 } Nrf mutant tested & glucose & formate & $\begin{array}{c}\text { Cytochrome } \\
c_{552} \text { concn } \dagger\end{array}$ \\
\hline JCB 323 & 8.9 & 10.9 & 235 \\
(parental strain) & & & \\
JCB351 & 1.1 & $<0.1$ & $<10$ \\
JCB352 & 2.1 & $<0.1$ & $\operatorname{tr}$. \\
JCB353 & 2.5 & $<0.1$ & $\operatorname{tr}$. \\
JCB354 & $<0.1$ & $<0.1$ & $<10$ \\
JCB355 & $<0.1$ & $<0.1$ & $<10$ \\
JCB362 & 0.6 & $<0.1$ & $\operatorname{tr}$. \\
JCB379 & 0.5 & 0.3 & $\operatorname{tr}$. \\
\hline \hline
\end{tabular}

* Nitrite reduced $\mathrm{min}^{-1}\left(\mathrm{mg}\right.$ bacterial dry mass) ${ }^{-1}$.

† pmol cytochrome (mg soluble protein) ${ }^{-1}$.

tr., Too little to quantify, but a very small spectral peak clearly visible: see fig. $2(b)$ for an example (JCB352).

cytochrome $c_{552}$ in the soluble fraction after high speed centrifugation was determined (Table 4).

Virtually no Nrf activity was detected with suspensions of any of the mutants tested and only very low residual rates of nitrite reduction by glucose were found. All of the mutants were deficient in $c$-type cytochromes, but some variations were noticed. For example, although the concentration of cytochrome $c_{552}$ in strain JCB352 was less than $10 \%$ of the parental strain, a clear peak of residual cytochrome was consistently seen in absorption spectra (Fig. 2). In contrast, no soluble cytochrome was ever detected in cultures of some of the other mutants such as JCB351 or JCB606. This was the first indication that the various $\mathrm{Nrf}^{-}$mutants were defective at different loci.

The insertion mutations of strains which had repeatedly been shown to be defective in Nrf activity by all of the above criteria were transferred by P1-mediated transduction to the $\mathrm{Nir}^{-} \mathrm{Nrf}^{+}$strain, JCB387, for further analysis. Some of the mutations were also transferred to a variety of $\mathrm{HFr}$ strains with different origins of chromosomal transfer, or to $\mathrm{F}^{-}$auxotrophic strains suitable for genetic mapping experiments. In most cases, the nir operon was first deleted from these strains to enable the Nrf phenotype of recombinants from subsequent experiments to be scored. In this way it was shown that strains MC4100, one culture (but not another!) of the HFrH strain CGSC 10235, CGSC 4517 and HFr P4X were all $\mathrm{Nrf}^{-}$.

\section{Chromosomal location of some of the mutations responsible for the $\mathrm{Nrf}^{-}$phenotypes}

In preliminary interrupted mating experiments with

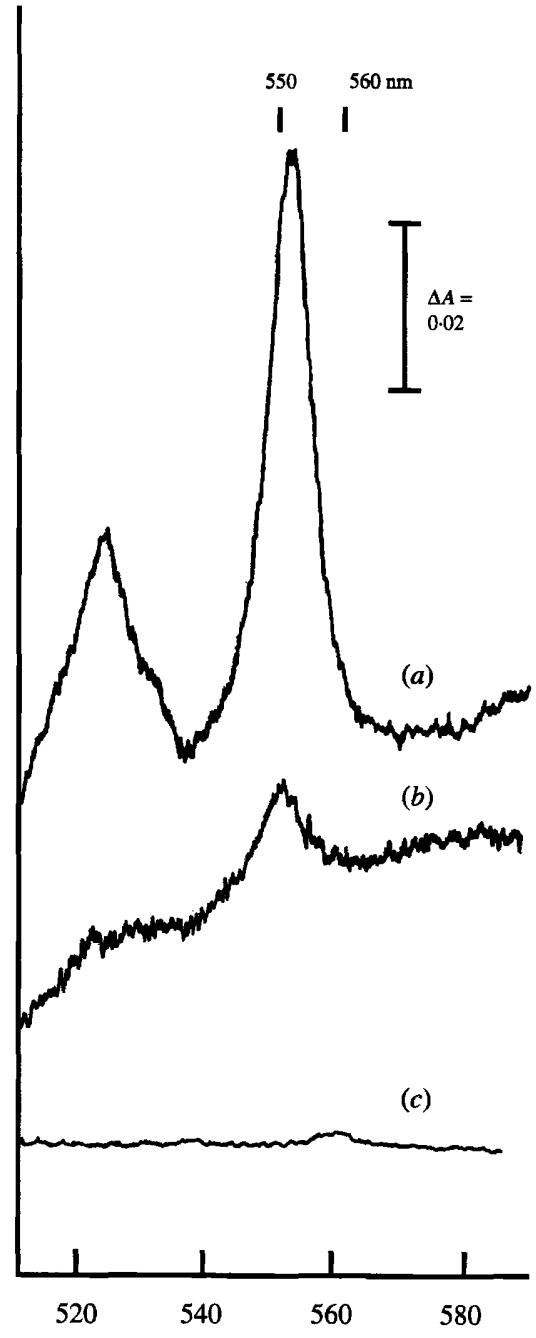

Fig. 2. Absorption spectra of soluble cytochromes from two $\mathrm{Nr}^{-}$ mutants and the parental strain, JCB387. Bacteria were grown anaerobially in 2 litre flasks filled with half-strength nutrient broth in minimal salts supplemented with $0.4 \%$ glucose and $2.5 \mathrm{~mm}$-nitrite. Bacteria were harvested by centrifugation, resuspended in $50 \mathrm{~mm}$ phosphate buffer, pH 7.4, and broken in a French press. Soluble proteins were prepared by centrifugation for $1 \mathrm{~h}$ at $150000 \mathrm{~g}$. One sample was reduced with a few grains of sodium dithionite; the reference sample was oxidized with a small crystal of potassium ferricyanide. The difference spectrum (reduced minus oxidized samples) was recorded. Protein concentrations were $13.5 \mathrm{mg} \mathrm{m}^{-1}$ (parental strain JCB387; spectrum $a$ ), $13.3 \mathrm{mg} \mathrm{ml}^{-1}$ (JCB352; spectrum $b$ ) and $4.6 \mathrm{~m} \mathrm{ml}^{-1}$ (JCB606; spectrum c).

antibiotic-resistant $\mathrm{Nrf}^{-} \mathrm{HFr}$ strains as the donor, many $\mathrm{Mel}^{+} \mathrm{Nrf}^{-}$recombinants were isolated, suggesting that some of the Nrf mutations were located in the 90 to 100 minute region of the $E$. coli chromosome. To investigate this further, a $\mathrm{Nir}^{-}$derivative of the $\mathrm{HFr}$ Cavalli strain, CGSC 4926, with defects in both mel and $m e t B$ genes, was the donor for uninterrupted mating experiments with various $\operatorname{Pur}^{-} \mathrm{Nrf}^{-}$narL: $: \operatorname{Tn} 10$ recipients: Ade $^{+}$Tet $^{\mathrm{R}}$ recombinants were selected (Table 5). Similar results were obtained in further conjugation 
Table 5. Analysis of recombinants obtained from conjugating an HFr Cavalli derivative, CGSC 4926, with adenine-auxotrophic $\mathrm{Nrf}^{-}$mutants

The donor strain was CGSC 4926 with the relevant genotype pur ${ }^{+}$ mel metB. nar $L^{+} ;$the recipients were narL: :Tn $10 \mathrm{Nrf}^{-} \lambda \mathrm{p} l a c \mathrm{Mu} 9$ derivatives of CGSC 4432. After $1 \mathrm{~h}$ of uninterrupted mating in Lennox broth at $37^{\circ} \mathrm{C}, \mathrm{Pur}^{+} \mathrm{Tet}^{\mathrm{R}}$ recombinants were selected and, after purification, analysed for the inheritance of unselected markers.

\begin{tabular}{rrrrrr}
\hline \hline & \multicolumn{5}{c}{ Nrf $^{-}$mutation in recipient } \\
\cline { 2 - 6 } Recombinant class & $n r f-602$ & $n r f-603$ & $n r f-604$ & $n r f-605$ & $n r f-606$ \\
\hline Ade $^{+} \mathrm{Met}^{+} \mathrm{Mel}^{+} \mathrm{Kan}^{\mathrm{R}}$ & 27 & 19 & 28 & 23 & 24 \\
$\mathrm{Mel}^{+} \mathrm{Kan}^{\mathrm{S}}$ & 0 & 0 & 1 & 9 & 5 \\
$\mathrm{Mel}^{-} \mathrm{Kan}^{\mathrm{R}}$ & 51 & 53 & 2 & 24 & 2 \\
$\mathrm{Mel}^{-} \mathrm{Kan}^{\mathrm{S}}$ & 0 & 1 & 39 & 21 & 35 \\
$\mathrm{Ade}^{+} \mathrm{Met}^{-} \mathrm{Mel}^{+} \mathrm{Kan}^{\mathrm{R}}$ & 0 & 0 & 0 & 0 & 0 \\
$\mathrm{Mel}^{+} \mathrm{Kan}^{\mathrm{S}}$ & 0 & 0 & 0 & 0 & 0 \\
$\mathrm{Mel}^{-} \mathrm{Kan}^{\mathrm{R}}$ & 6 & 9 & 0 & 5 & 0 \\
$\mathrm{Mel}^{-} \mathrm{Kan}^{\mathrm{S}}$ & 0 & 0 & 15 & 5 & 12 \\
\hline \hline
\end{tabular}

experiments with $\mathrm{Nrf}^{-} \mathrm{Amp}^{\mathrm{R}}$ derivatives of CGSC 4432 (not shown). Analysis of the recombinants revealed that the antibiotic resistance determinants associated with the Nrf insertion mutations were located in at least three separate segments of the chromosome.

The significant numbers of antibiotic-sensitive, $\mathrm{Mel}^{-}$ recombinants in matings with recipients carrying the mutations from $\mathrm{Nrf}^{-}$strains JCB351, 362, 379, 604 and 606 indicated that the defective $n r f$ genes in these strains were located in the 90 to 95 minute region of the chromosome (Fig. $3 a$ ). The mutations in this group were transferred to an $\mathrm{F}^{-}$met $B$ strain, and $\mathrm{F}^{\prime} 112$, which includes chromosomal DNA from the 88 to 98 minute region of the $E$. coli chromosome, was transferred into these mutants by conjugation with selection for $\mathrm{Met}^{+}$. The exconjugants were all $\mathrm{Nrf}^{+}$.

In contrast to the majority of mutants screened, all of the recombinants from matings with recipients with mutations from strains $\mathrm{JCB} 602$ and 603 were $\mathrm{Kan}^{\mathrm{R}}$, consistent with the $n r f$ mutations being located in the 40 to 80 minute segment of the chromosome. Conversely, the pattern of inheritance of unselected markers in matings with a recipient carrying the mutation from strain JCB605 implied that the defective $n r f$ gene was located between purA at minute 95 and the origin of transfer at minute 13 (Table 5; Fig. $3 a$ ).

Co-transduction of the $\mathrm{Nrf}^{-}$phenotype of $\mathrm{E}$. coli strain FM932 with fdhF

Some of the Nrf mutations, which in conjugation experiments appeared to be linked to the mel operon, were mapped more precisely by transduction using mel (a)

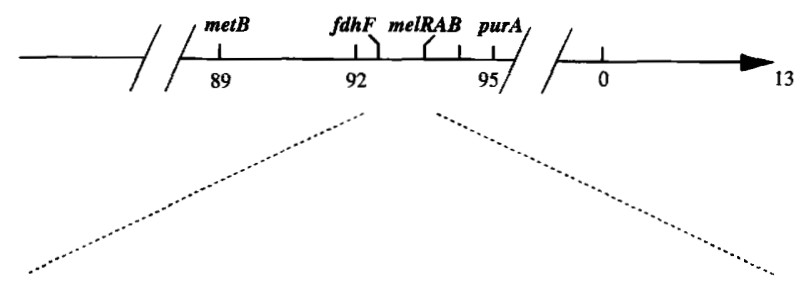

(b)

fdhF

melRAB
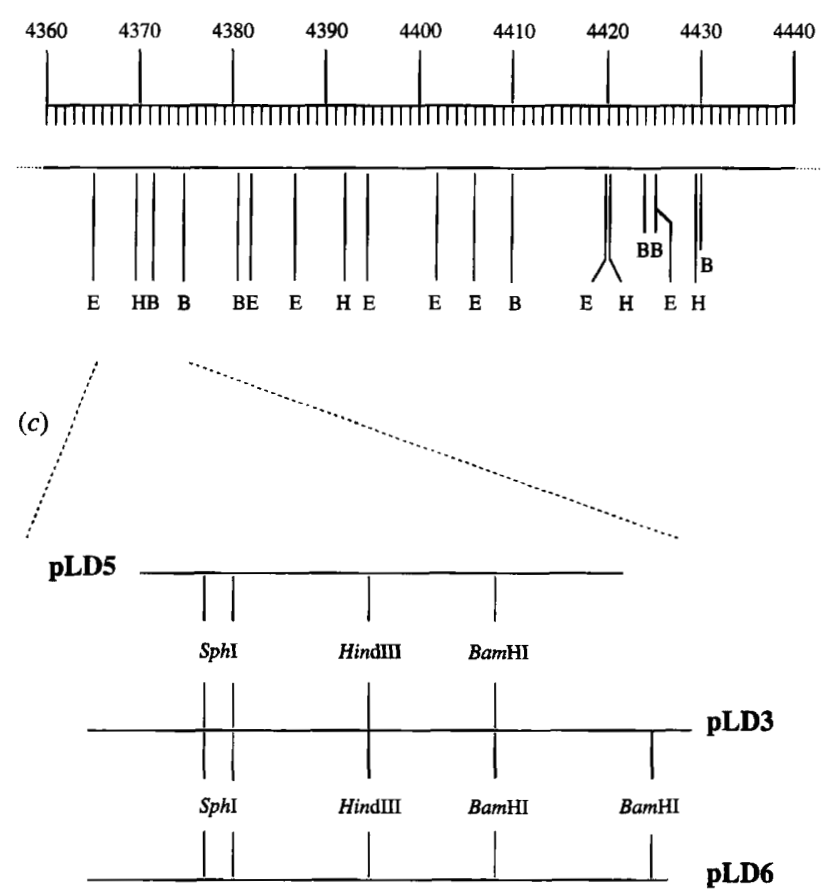

Fig. 3. Region of the $E$. coli chromosome in which various mutations conferring a $\mathrm{Nrf}^{-}$phenotype were located. (a) The arrowhead indicates the origin of chromosomal transfer by the HFr strain CGSC 4926. The positions of relevant genes in the 88 to 98 region of the chromosome are also indicated. (b) The physical map of the $f d h F$ to mel region, as reported by Kohara et al. (1987). (c) Partial restriction maps of three plasmids which complement several of the $n r f$ mutations located in the 92 minute region of the chromosome.

and $f d h F$ mutations as the reference markers. First, the temperature-stabilized $f d h F$ deletion strain FM932 was transduced to $c y s G:: \operatorname{Tn} 5$ to inactivate the Nir pathway and then checked for Nrf activity. Unexpectedly, all of the transductants were both $\mathrm{Nir}^{-}$and $\mathrm{Nrf}^{-}$. Strain FM932 had been constructed from MC4100 in three steps: insertional inactivation of $f d h F$ with Mud1Aplac to give the temperature-sensitive $f d h F$ mutant, M9; temperature stabilization, which resulted in the deletion of $f d h F$ and an unknown length of adjacent DNA, and transduction to mel::Tn10 (Pecher et al., 1985). Although the $\mathrm{Nrf}^{-}$phenotype of FM932 was the first indication (shown above to be incorrect) that $f d h F$ might 
Table 6. Formate-dependent nitrite reduction and cytochrome $c_{552}$ synthesis by E. coli strain MC4100 and its derivatives

Bacteria were grown anaerobically in unshaken, deep standing cultures in NCM supplemented with $0.4 \%$ glycerol, $40 \mathrm{mM}-$ fumarate and $2.5 \mathrm{~mm}$-nitrite. The chloroform method was used to extract periplasmic cytochrome $c_{552}$ in these experiments.

\begin{tabular}{lcc}
\hline \hline \multicolumn{1}{c}{ Strain } & $\begin{array}{c}\text { Nitrite reduction } \\
\text { by formate* }\end{array}$ & $\begin{array}{c}\text { Cytochrome } c_{552} \\
\text { concn }{ }^{*}\end{array}$ \\
\hline MC4100 nirB & $<0 \cdot 1$ & 106 \\
MC4100 cys $::$ Tn5 & $<0 \cdot 1$ & 88 \\
MC4100 cys $G:: \operatorname{Tn} 5 \mathrm{Nrf}^{+}$ & $22 \cdot 2$ & 422 \\
M9 cys $G:: \operatorname{Tn} 5$ & $<0 \cdot 1$ & 94 \\
M9 cys $G:: \operatorname{Tn} 5 \mathrm{Nrf}^{+}$ & $29 \cdot 4$ & 401 \\
JCB387 nirB & $17 \cdot 0$ & 389 \\
\hline
\end{tabular}

*nmol nitrite reduced $\mathrm{min}^{-1}$ (mg bacterial dry mass) ${ }^{-1}$. $\dagger$ pmol cytochrome (mg soluble protein) ${ }^{-1}$.

be essential for Nrf activity, it was also possible that an independent but essential $n r f$ gene as well as $f d h F$ had been deleted, or that the parental strain MC4100 was $\mathrm{Nrf}^{-}$. To resolve these uncertainties, cysG::Tn5 derivatives of both MC4100 and M9 were constructed by transduction. Glucose- and formate-dependent rates of nitrite reduction of the various MC4100 strains were then compared with strain JCB387 (Table 6). The Nrf activities of both strains $\mathrm{M} 9$ cys $G$ and $\mathrm{MC} 4100$ cys $G$ were less than $0.5 \%$ of that of JCB387, but cytochrome $c_{552}$ was readily detected.

In a further series of transductions in which JCB387 was used as the donor, a temperature-stabilized, $\mathrm{Nrf}^{+} \mathrm{Nir}^{-}$derivative of $\mathrm{M} 9$ was isolated. The Nrf activity and concentration of cytochrome $c_{552}$ in these strains were comparable to those of strain JCB387 (Table 6). This result established not only that strain MC4100 and the various $f d h F$ mutants derived from it are $\mathrm{Nrf}^{-}$, but also that the defective $n r f$ genes in these strains are cotransducible with $f d h F$.

\section{Isolation of cosmids which complement some of the Nrf mutations}

Attempts to isolate cosmids which transform the $\mathrm{Nrf}^{-}$ strain JCB6061 to $\mathrm{Nrf}^{+}$were unsuccessful. Although several transformants were initially $\mathrm{Nrf}^{+}$, they were $\mathrm{Nrf}^{-}$ when retested. Attempts to subclone complimentary $n r f^{+}$ DNA from these clones into multi-copy plasmids were also unsuccessful.

The high frequency of co-transduction of the $\mathrm{Nrf}^{-}$ phenotype of FM932 with the mel::Tn10 insertion suggested that the deleted $n r f$ genes were probably located between the $f d h F$ and mel operons and therefore provided an alternative strategy for cloning the deleted genes. The $f d h F$ and $m e l$ genes are $0.8 \mathrm{~min}$ or about $40 \mathrm{~kb}$ apart on the $E$. coli chromosome (Fig. $3 b$ ): as up to $50 \mathrm{~kb}$ of bacterial DNA can be incorported into a cosmid, it should be possible to clone all of this intervening DNA by isolating cosmids which complement either or both the mel: :Tn 10 and the $f d h F$ defects of strain FM932.

The $\mathrm{Fdh}^{-} \mathrm{Nrf}^{-} \mathrm{Mel}^{-}$defects of FM932 were transferred by transduction to JCB387 to give JCB3878 which was then transformed with the cosmid library. Approximately 1000 of the several thousand $\mathrm{Amp}^{\mathrm{R}}$ clones generated in this experiment were purified onto selective agar plates, screened individually for formate hydrogenlyase activity $\left(f d h F^{+}\right)$and ability to grow on minimal agar with melibiose as sole carbon source. All of the $\mathrm{Mel}^{+}$or $\mathrm{Fhl}^{+}$clones were then tested for Nrf activity. Nine $\mathrm{Mel}^{+}$clones were all $\mathrm{Nrf}^{-}$, but three out of eight $\mathrm{Fhl}^{+}$clones were $\mathrm{Nrf}^{+}$. As no $\mathrm{Mel}^{+} \mathrm{Nrf}^{+}$clones were isolated, it was apparent the $n r f$ genes were closer to $f d h F$ than to the mel operon.

Cosmid DNA from two independent clones was partially digested with Sau3A and fragments in the range 6 to $15 \mathrm{~kb}$ were subcloned into the BamHI site of the low copy number vector, pLG339. The ligated DNA was transformed into JCB3878 and, after purification, colonies transformed with $\mathrm{Kan}^{\mathrm{R}} \mathrm{Tet}^{\mathrm{S}}$ recombinant plasmids were screened for $\mathrm{Nrf}$ activity. Five $\mathrm{Nrf}^{+}$clones were isolated from bacteria transformed with DNA from one of the cosmids and one $\mathrm{Nrf}^{+}$clone was derived from the second cosmid. The restriction maps of three of these plasmids, which revealed several common fragments (Fig. 3c), corresponded exactly with the published restriction map of the chromosome close to but on the opposite side of $f d h F$ to $m e l$. From the size and restriction map of plasmid pLD5, the smallest sub-clone which restored a $\mathrm{Nrf}^{+}$phenotype, it can be concluded that the $n r f$ genes deleted from FM932 and JCB3878 are located between coordinates 4365 and 4374 on the Kohara map (Fig. $3 b, c$; Kohara et al., 1987). None of the sub-clones carried a functional $f d h F^{+}$gene.

\section{Complementation of other mutations with the recombinant plasmids}

The only antibiotic resistance marker encoded by pLD5 is $\mathrm{Kan}^{\mathrm{R}}$. The $9 \mathrm{~kb}$ Eco RI-SalI fragment, which included all of the $E$. coli DNA, was therefore sub-cloned into pBR322 which had been digested with the same enzymes to provide a plasmid which could be used to transform $\mathrm{Kan}^{\mathrm{R}} \mathrm{Nrf}^{-}$mutants to $\mathrm{Amp}^{\mathrm{R}}$. The resulting plasmid, pLD5R, was then shown to transform JCB3878 to $\mathrm{Nrf}^{+}$.

All of the $\mathrm{Nrf}^{-}$strains with mutations mapped to the 92 to 94 minute region of the chromosome were each transformed with either pLD5 or pLD5R and the Nrf phenotypes of the purified transformants were determined. Strains JCB352, 353, 362 and 602 were all 
Table 7. Location by PI-mediated transduction of three groups of nrf genes in the 92 to 94 minute region of the E. coli chromosome

The numbers of each class of recombinant analysed were typically in the range 72 to 144 .

\begin{tabular}{|c|c|c|c|c|}
\hline Donor (phenotype) genotype & Recipient (phenotype) genotype & $\begin{array}{c}\text { Selected } \\
\text { marker }\end{array}$ & $\begin{array}{l}\text { Transduction } \\
\text { classes }\end{array}$ & $\begin{array}{l}\text { Frequency } \\
(\%)\end{array}$ \\
\hline \multicolumn{5}{|l|}{ Expt 1} \\
\hline \multirow[t]{2}{*}{$\begin{array}{l}\mathrm{JCB} 6069\left(\mathrm{Kan}^{\mathrm{R}} \mathrm{Tet}^{\mathrm{R}}\right) \\
n r f-606 \text { mel: : } \operatorname{Tn} 10\end{array}$} & M9 $\Delta$ nir $\left(\mathrm{Nrf}^{+} \mathrm{Fhl}^{-}\right) f d h F n r f^{+}$ & $\mathrm{Tet}^{\mathrm{R}}$ & $\begin{array}{l}\mathrm{Fhl}^{-} \mathrm{Nrf}^{-} \\
\mathrm{Fhl}^{-} \mathrm{Nrf}^{+} \\
\mathrm{Fhl}^{+} \mathrm{Nrf}^{-} \\
\mathrm{Fhl}^{+} \mathrm{Nrf}^{+}\end{array}$ & $\begin{array}{r}10 \\
39 \\
51 \\
0\end{array}$ \\
\hline & & $\operatorname{Kan}^{\mathrm{R}}$ & $\begin{array}{l}\mathrm{Fhl}^{-} \mathrm{Mel}^{-} \\
\mathrm{Fhl}^{-} \mathrm{Mel}^{+} \\
\mathrm{Fhl}^{+} \mathrm{Mel}^{+} \\
\mathrm{Fhl}^{+} \mathrm{Mel}^{-}\end{array}$ & $\begin{array}{r}38 \\
62 \\
0 \\
0\end{array}$ \\
\hline \multicolumn{5}{|l|}{ Expt 2} \\
\hline $\begin{array}{l}\text { FM932 }\left(\mathrm{Fhl}^{-} \mathrm{Nrf}^{-} \mathrm{Tet}^{\mathrm{R}}\right) \\
\text { fdhF mel: :Tn10 }\end{array}$ & JCB606 $\left(\mathrm{Nrf}^{-} \mathrm{Kan}^{\mathrm{R}}\right) n r f-606$ & $\operatorname{Tet}^{R}$ & $\begin{array}{l}\mathrm{Fhl}^{-} \mathrm{Kan}^{\mathrm{R}} \mathrm{Nrf}^{-} \\
\mathrm{Fhl}^{-} \mathrm{Kan}^{\mathrm{S}} \mathrm{Nrf}^{-} \\
\mathrm{Fhl}^{+} \mathrm{Kan}^{\mathrm{R}} \mathrm{Nrf}^{-} \\
\mathrm{Fhl}^{+} \mathrm{Kan}^{\mathrm{S}} \mathrm{Nrf}^{+}\end{array}$ & $\begin{array}{l}49 \\
14 \\
15 \\
22\end{array}$ \\
\hline \multicolumn{5}{|l|}{ Expt 3} \\
\hline \multirow[t]{2}{*}{ JCB362 $\left(\mathrm{Nrf}^{-} \mathrm{Amp}^{\mathrm{R}}\right) n r f-362$} & $\begin{array}{l}\text { FM932 }\left(\mathrm{Fhl}^{-} \mathrm{Nrf}^{-} \mathrm{Tet}^{\mathrm{R}}\right) \\
\text { fdhF mel: :Tn10 }\end{array}$ & $\mathrm{Mel}^{+}$ & $\begin{array}{l}\mathrm{Amp}^{\mathrm{R}} \mathrm{Fhl}^{+} \\
\mathrm{Amp}^{\mathrm{R}} \mathrm{Fhl}^{-} \\
\mathrm{Amp}^{\mathrm{S}} \mathrm{Fh}^{+} \\
\mathrm{Amp}^{\mathrm{S}} \mathrm{Fhl}^{-}\end{array}$ & $\begin{array}{r}0 \\
21 \\
7 \\
72\end{array}$ \\
\hline & & $A m p^{R}$ & $\begin{array}{l}\mathrm{Mel}^{+} \mathrm{Fhl}^{+} \\
\mathrm{Mel}^{+} \mathrm{Fhl}^{-} \\
\mathrm{Mel}^{-} \mathrm{Fhl}^{+} \\
\mathrm{Mel}^{-} \mathrm{Fhl}^{-}\end{array}$ & $\begin{array}{r}0 \\
9 \\
82 \\
9\end{array}$ \\
\hline \multirow[t]{2}{*}{$\begin{array}{l}\text { Expt } 4 \\
\quad \text { JCB3513 }\left(\mathrm{Nrf}^{-} \mathrm{Amp}^{\mathrm{R}}\right) \text { nrf-351 }\end{array}$} & $\begin{array}{l}\text { FM932 }\left(\mathrm{Fhl}^{-} \mathrm{Nrf}^{-} \mathrm{Tet}^{\mathrm{R}}\right) \\
\text { fdhF mel: :Tn10 }\end{array}$ & $A m p^{R}$ & $\begin{array}{l}\mathrm{Fhl}^{+} \mathrm{Mel}^{+} \\
\mathrm{Fhl}^{+} \mathrm{Mel}^{-} \\
\mathrm{Fhl}^{-} \mathrm{Mel}^{+} \\
\mathrm{Fhl}^{-} \mathrm{Mel}^{-}\end{array}$ & $\begin{array}{r}0 \\
63 \\
9 \\
28\end{array}$ \\
\hline & & $\mathrm{Mel}^{+}$ & $\begin{array}{l}\mathrm{Fhl}^{+} \mathrm{Amp} \mathrm{p}^{\mathrm{R}} \\
\mathrm{Fhl}^{+} \mathrm{Amp} \mathrm{s}^{\mathrm{R}} \\
\mathrm{Fhl}^{-} \mathrm{Amp} \mathrm{R}^{\mathrm{R}} \\
\mathrm{Fhl}^{-} \mathrm{Amp} \mathrm{s}^{\mathrm{s}}\end{array}$ & $\begin{array}{r}0 \\
0 \\
8 \\
92\end{array}$ \\
\hline
\end{tabular}

transformed to $\mathrm{Nrf}^{+}$by these plasmids, as were the $\mathrm{Nrf}^{-}$ HFrH strain CGSC 10235 and MC4100 (Anir). In contrast, transformants of strains JCB351, 354, 355, 356, $603,604,605$ and 606 were $\mathrm{Nrf}^{-}$. As the mutations carried by the latter strains are all co-transducible with either $m e l$ or $f d h F$, it is apparent that genes essential for formate-dependent nitrite reduction are located in several separate loci in this region.

At least three loci required for formate-dependent nitrite reduction are located in the 92 to 94 minute region of the E. coli chromosome

Some of the recombinants from the initial transduction experiments provided strains suitable for the fine structure mapping of other $n r f$ genes in the 92 to 94 minute region of the chromosome. In the first experiment (Table 7), a mel:: $\operatorname{Tn} 10$ derivative of the $\lambda$ plac $\mathrm{Mu}$ insertion in strain JCB606 was used as donor to locate the $n r f-606$ mutation to the opposite side of the mel operon to $f d h F$. The recipient, JCB3406, was a $\mathrm{Nir}^{-} \mathrm{Nrf}^{+}$derivative of the $f d h F$ mutant $\mathrm{M} 9$. All of the $\mathrm{Kan}^{\mathrm{R}}$ transductants tested were $\mathrm{FdhH}^{-}$(Table 7). In contrast, selection for $\mathrm{Tet}^{\mathrm{R}}$ resulted in both $\mathrm{Tet}^{\mathrm{R}} \mathrm{Kan}^{\mathrm{R}}$ and $\mathrm{Tet}^{\mathrm{R}} \mathrm{FdhH}^{+}$ transductants, consistent with mel:: $\operatorname{Tn} 10$ being the middle marker, but again none of the transductants were both $\mathrm{FdhH}^{+}$and $\mathrm{Kan}^{\mathrm{R}}$, presumably because the distance between either side of these two mutations is too great for all of the intervening DNA to be packaged into bacteriophage P1 (see Fig. 3). In a subsequent experiment, the relative positions of the $n r f-606$ and FM932 $\mathrm{Nrf}^{-}$mutations were determined using bacteriophage P1 prepared on the mel::Tn10 strain, FM932 (experiment 2, Table 7). Of the $\mathrm{Tet}^{\mathrm{R}}$ transductants selected, $64 \%$ were also $\mathrm{Kan}^{\mathrm{R}}$; the majority of these transductants had also inherited the $f d h F$ deletion of the donor. Most significant, however, were the $14 \%$ that were $\mathrm{Fhl}^{-} \mathrm{Kan}^{\mathrm{s}}$ : although these transductants had not inherited the $n r f-606 \mathrm{mu}-$ 
tation, they were all nevertheless $\mathrm{Nrf}^{-}$. This clearly established that the deletion that resulted in temperature stabilization of the $f d h F$ insertion had also resulted in the loss of a gene adjacent to $f d h F$ which is essential for $\mathrm{Nrf}$ activity. Consistent with this conclusion was the failure to isolate any $\mathrm{Fhl}^{-} \mathrm{Nrf}^{+}$transductants in which the $f d h F$ deletion had been separated from the defective $n r f$ gene.

The transductants isolated from the above experiments were useful for mapping other $n r f$ mutations located in the 92 to 94 minute region. In this way, the $n r f-352, n r f-$ $353, n r f-362$ and $n r f-379$ mutations were located in the same region as the $n r f$ deletion in FM932 (see, for example, experiment 3 of Table 7). Finally, a third locus required for Nrf activity which is defective in JCB351 and located between the $f d h F$ and $m e l$ genes was identified (experiment 4 of Table 7; Fig. 3). Further evidence consistent with these proposed map locations came from the isolation of a temperature-stabilized $\mathrm{Nrf}^{-} \mathrm{FdhH}^{-} \mathrm{Mel}^{+}$deletion derivative of JCB362 and a $\mathrm{Nrf}^{-} \mathrm{FdhH}^{+} \mathrm{Mel}^{-}$deletion derivative of JCB351.

\section{Discussion}

\section{Electron transfer from formate into the Nrf pathway}

As energy is conserved during both formate-dependent nitrite and nitrate reduction but not during formate hydrogenlyase activity, it was initially expected that FdhN would be essential for the transfer of electrons from formate to the Nrf complex. Surprisingly, an $\mathrm{FdhN}^{-}$strain was $\mathrm{Nrf}^{+}$and, conversely, the $f d h F$ deletion mutant FM932 was Nrf $^{-}$. The simple interpretation of these results, that FdhH is essential for Nrf activity, was known to be incorrect because although transcription of the $f d h F$ gene requires the alternative sigma factor, sigma 54 encoded by rpoN, an rpoN mutant was shown to be $\mathrm{Nrf}^{+}$(Birkman et al., 1987; Page et al., 1990). These uncertainties were resolved by establishing that all three known formate dehydrogenases contribute to the transfer of electrons from formate to nitrite (Table 2) and that the $\mathrm{Nrf}^{-}$defect of strain FM932 is due to the deletion of genes close to but independent of $f d h F$ at minute 92.6 on the $E$. coli chromosome (Fig. 3). Further confirmation of these conclusions was provided by ${ }^{75} \mathrm{Se}$ labelling experiments, which failed to reveal a fourth, previously undescribed selenoprotein. As FdhO is only poorly expressed (Sawers et al., 1991; Fig. 1) and contributes less than $10 \%$ to the total Nrf activity, we conclude that the Nrf pathway primarily exploits the presence of two major formate dehydrogenases involved in other modes of anaerobic growth to transfer electrons from formate to cytochrome $c_{552}$.

Rates of formate-dependent nitrite reduction by washed bacteria were decreased by approximately $50 \%$ by mutations resulting in the loss of either of the two major formate dehydrogenases, $\mathrm{FdhN}$ or $\mathrm{FdhH}$, and the effects of these mutations were essentially additive (Table 2). If the electron flux from formate to cytochrome $c_{552}$ is determined primarily by the sum of the activities of these two enzymes, the consequence of high flux coefficients for these dehydrogenases is that the electron flux to nitrite is relatively insensitive to large changes in the quantity of cytochrome $c_{552}$ synthesized. This is particularly significant because, apart from a slight induction of FdhN synthesis by nitrite (Berg \& Stewart, 1990), neither of the dehydrogenases is synthesized optimally under growth conditions in which cytochrome $c_{552}$ synthesis and Nrf pathway activity are induced. Furthermore, the residual activity of the $\mathrm{FdhN}^{-} \mathrm{FdhH}^{-}$ double mutant establishes that the poorly expressed FdhO is competent in electron transfer from formate to nitrite as well as to oxygen and nitrate (see Pommier et al., 1992).

Fujita \& Sato (1967) reported that nitrite inhibits the production of $\mathrm{H}_{2}$ from glucose by bacteria grown in the absence of nitrate or nitrite. The production of $\mathrm{CO}_{2}$ was concomitantly enhanced and nitrite was reduced to ammonia. These early observations can now be interpreted on the basis of competition between hydrogenase 3 and cytochrome $c_{552}$ for electrons from FdhH. How electrons are transferred from $\mathrm{FdhH}$ to the cytochrome is unclear. Possibly the membrane-spanning proteins $\mathrm{HycC}$ and $\mathrm{HycD}$, together with components of the quinone pool, are involved. Alternatively, unknown components of the Nrf pathway might be required to interact directly with $\mathrm{FdhH}$ without the involvement of quinones. If so, this could explain why a mutant deficient in ubiquinone and menaquinone synthesis retained $60 \%$ of the Nrf activity of the parental strain (Abou-Jaoude et $a l ., 1979 b$ ). The demonstration that the electrogenic FdhN can donate electrons to the Nrf pathway explains how energy is conserved and the involvement of a $b$-type cytochrome in Nrf activity (Motteram et al., 1981; Pope \& Cole, 1982; Abou-Jaoudé et al., 1979b). The FdnI component of $\mathrm{FdhN}$ is cytochrome $b_{556}$ (Berg et al., 1991) and is probably involved in the transfer of electrons from formate to the quinone pool. We suggest that this is the point at which electron transfer to nitrate or nitrite diverges when FdhN is involved in formate oxidation.

Although several of the strains used for the experiments summarized in Table 2 were devoid of both of the two major pathways for nitrite reduction, they were all $\mathrm{Nrf}^{+}$, as judged by the test-tube assay for the $\mathrm{Nrf}$ phenotypes of recombinants for genetic experiments. This indicates that metabolites of glucose other than formate and NADH can act as electron donors for nitrite reduction. Possible candidates for these alternative electron donors include lactate (Abou-Jaoudé et al., 
1979a) and ethanol (Pope \& Cole, 1984). Even the selC strain, JCB3881, was phenotypically $\mathrm{Nrf}^{+}$, as judged by the test-tube assay used to screen recombinants from a genetic experiment in which the concentration of nitrite used was only $0.25 \mathrm{~mm}$. In contrast, $\mathrm{Sel}^{-}$strains failed to reduce the $1 \mathrm{~mm}$-nitrite used in initial $\mathrm{Nrf}$ tests to screen the libraries of transposon insertion mutants (Table 3).

In summary, we suggest that energy is conserved during nitrite reduction primarily when $\mathrm{FdhN}$ donates electrons via the quinone pool to cytochrome $c_{552}$. It remains to be established whether the transfer of electrons from FdhH merely serves to detoxify nitrite in the periplasm without the generation of a membrane potential.

\section{Location of genes essential for Nrf activity}

Several difficulties had to be overcome for the various $n r f$ mutations to be mapped. First, the Nrf phenotype of recombinants could only be scored if both the donor and the recipient were first made $\mathrm{Nir}^{-}$by a series of transduction and screening procedures. Secondly, if either the donor or the recipient was $\mathrm{Nir}^{+}$, streptomycin resistance of the recipient could not be used as a counterselective marker because of the proximity of the streptomycin-resistance determinant, $r p s L$, to the nir operon (Macdonald et al., 1985). To overcome this limitation, a nar $L:: \operatorname{Tn} 10$ mutation was introduced into the recipient strain. A further complication was that many attempts to devise a medium selective for $\mathrm{Nrf}^{+}$ recombinants were unsuccessful. The simplest way to distinguish between $\mathrm{Nrf}^{+}$and $\mathrm{Nrf}^{-}$recombinants from genetic crosses was therefore to score for inheritance of antibiotic resistance associated with the insertion mutations. As phenotypic expression is required for full resistance to both ampicillin and kanamycin to develop, it was necessary to arrange for the various $n r f$ mutations to be located in the recipient used for conjugation experiments.

The approximate locations of most of the $n r f$ mutations have been established in a series of uninterrupted conjugation experiments with an HFr Cavalli derivative as the donor and antibiotic-resistant $\mathrm{Nrf}^{-} \mathrm{Pur}^{-}$ strains as the recipients. Mutations located in the 92 to 94 minute region were subsequently further sub-divided on the basis of bacteriophage-P1-mediated transduction data. The combined results establish that at least five loci, three of them in the 92 to 94 minute region, are essential for Nrf activity. Experiments currently in progress indicate that the structural gene for cytochrome $c_{552}$ is located on plasmid pLD5. Possible functions for the products of the other genes include electron transfer from the various formate dehydrogenases to cytochrome $c_{552}$, the attachment of haem to the apoprotein catalysed by a haem lyase, the transport of a mature cytochrome $c_{552}$ across the cytoplasmic membrane or the assembly of cytochrome $c_{552}$ from protoporphyrin IX and the apoprotein in the periplasm (Page \& Ferguson, 1990; Ramseier et al., 1991).

This research was supported by a Project Grant from the SERC to J.A.C. and SERC Research Studentships to A. Darwin and L. Page. The authors gratefully acknowledge receipt of many useful strains and helpful ideas from B. Bachmann, A. Bock, D. Boxer, S. Busby, M. Chippaux, J. A. DeMoss, M.-A. Mandrand and V. Stewart and thank A. Bock for encouraging P.T. to complete his Diplomarbeit in Birmingham.

\section{References}

Abou-Jaoudé, A., Chippaux, M. \& PASCAL, M.-C. (1979a). Formatenitrite reduction in Escherichia coli K12. 1. Physiological study of the system. European Journal of Biochemistry 95, 309-314.

Abou-JaOUdÉ, A., PASCAL, M. C. \& ChIPPAUX, M. (1979b). Formatenitrite reduction in Escherichia coli K12. 2. Identification of components involved in the electron transfer. European Journal of Biochemistry 95, 315-321.

Ames, G. F.-L., Prody, C. \& Kustu, S. (1984). Simple, rapid and quantitative release of periplasmic proteins by chloroform. Journal of Bacteriology 160, 1181-1183.

BERG, B. \& STEWART, V. (1990). Structural genes for nitrate-inducible formate dehydrogenase in Escherichia coli. Genetics 125, 691-702.

Berg, B. L., LI, J., HeIDER, J. \& STEWART, V. (1991). Nitrate-inducible formate dehydrogenase in Escherichia coli K-12. 1. Nucleotide sequence of the $f d n G H I$ operon and evidence that opal (UGA) encodes selenocysteine. Journal of Biological Chemistry 266, 22380-22385.

Birkman, A., Sawers, R. G. \& Bock, A. (1987). Involvement of the $n \operatorname{tr} A$ gene product in the anaerobic metabolism of Escherichia coli. Molecular and General Genetics 210, 535-542.

Bremer, E., Silhavy, T. J., WeisemanN, J. M. \& Weinstock, G. M. (1984). $\lambda$ placMul, a transposable derivative of bacteriophage lambda for creating lac $Z$ protein fusions in a single step. Journal of Bacteriology 158, 1084-1093.

Bremer, E., Silhavy, T. J. \& Weinstock, G. M. (1985). Transposable $\lambda$ plac $\mathrm{Mu}$ bacteriophages for creating lac $Z$ operon fusions and kanamycin resistance insertions in Escherichia coli. Journal of Bacteriology 162, 1092-1099.

Casadaban, M. J. \& Cohen, S. N. (1979). Lactose genes fused to exogenous promoters in one step using a $\mathrm{Mu}$-lac bacteriophage: in vivo probe for transcriptional control sequences. Proceedings of the National Academy of Sciences of the United States of America 76, $4530-4533$.

CHESNEY, R. H., SCOTT, J. R. \& VAPNER, D. (1979). Integration of the plasmid prophages P1 and P7 into the chromosome of Escherichia coli. Journal of Molecular Biology 130, 161-173.

COLE, J. A. (1988). Assimilatory and dissimilatory reduction of nitrate to ammonia. Symposia of the Society for General Microbiology 42, 281-329.

Cox, J. C., Edwards, E. S. \& DeMoss, J. A. (1981). Resolution of distinct selenium-containing formate dehydrogenases from Escherichia coli. Journal of Bacteriology 145, 1317-1324.

FujITA, T. (1966). Studies on soluble cytochromes in Enterobacteriaceae. I. Detection, purification and properties of cytochrome $c_{552}$ in anaerobically grown cells. Journal of Biochemistry 60, 204-215.

FuITA, T. \& SATo, R. (1966a). Studies on soluble cytochromes in Enterobacteriaceae. III. Localization of cytochrome $c_{552}$ in the surface layer of cells. Journal of Biochemistry 60, 568-577.

Fujita, T. \& Sato, R. (1966b). Studies on soluble cytochromes in Enterobacteriaceae. IV. Possible involvement of cytochrome $c_{552}$ in anaerobic nitrite metabolism. Journal of Biochemistry 60, 691-700.

Fujita, T. \& Sato, R. (1967). Studies on soluble cytochromes in 
Enterobacteriaceae. V. Nitrite-dependent gas evolution in cells containing cytochrome $c_{552}$. Journal of Biochemistry 62, 230-238.

GRIFFITHS, L. \& COLE, J. A. (1987). Lack of redox control of the anaerobically-induced nir B gene of Escherichia coli K-12. Archives of Microbiology 147, 364-369.

HaRborne, N. R., Griffiths, L., Busby, S. J. W. \& Cole, J. A. (1992). Transcriptional control, translation and function of the products of the five open reading frames of the Escherichia coli nir operon. Molecular Microbiology 6, 2805-2813.

KAJIE, S. \& ANRAKU, Y. (1986). Purification of a hexaheme cytochrome $c_{552}$ from Escherichia coli $\mathrm{K} 12$ and its properties as a nitrite reductase. European Journal of Biochemistry 154, 357-363.

Kohara, Y., AkIYama, K. \& Isono, K. (1987). The physical map of the whole $E$. coli chromosome: application of a new strategy for rapid analysis and sorting of a large genomic library. Cell 50, 495-508.

Leinfelder, W., ForchHaMmer, K., Zinoni, F., SAWERs, G., MANDRAND-BERTHELOT, M.-A. \& Bock, A. (1988). Escherichia coli genes whose products are involved in selenium metabolism. Journal of Bacteriology 170, 540-546.

Macdonald, H. M., Pope, N. R. \& Cole, J. A. (1985). Isolation, characterization and complementation analysis of nir $B$ mutants of Escherichia coli deficient only in NADH-dependent nitrite reductase activity. Journal of General Microbiology 131, 2771-2782.

Maniatis, T., Fritsch, E. F. \& Sambrook, J. (1982). Molecular Cloning: a Laboratory Manual. Cold Spring Harbor, NY: Cold Spring Harbor Laboratory.

MaNOIL, C. \& BECKWITH, J. (1985). TnphoA transposon probe for protein export signals. Proceedings of the National Academy of Sciences of the United States of America 82, 8129-8133.

MotTeram, P. A. S., MCCARTHY, J. E. G., Ferguson, S. J., JaCkson, J. B. \& ColE, J. A. (1981). Energy conservation during the formatedependent reduction of nitrite by Escherichia coli. FEMS Microbiology Letters 12, 317-320.

PAGE, M. D. \& Ferguson, S. J. (1990). Apo forms of cytochrome $c_{550}$ and cytochrome $c d_{1}$ are translocated to the periplasm of Paracoccus denitrificans in the absence of haem incorporation caused by either mutation or inhibition of haem synthesis. Molecular Microbiology 4 , 1181-1192.

Page, L., Griffiths, L. \& Cole, J. A. (1990). Different physiological roles for two independent pathways for nitrite reduction to ammonia by enteric bacteria. Archives of Microbiology 154, 349-354.

Pecher, A., Zinoni, F., JATisatienr, C., WiRTh, R., Hennecke, H. \& Bock, A. (1983). On the redox control of synthesis of anaerobically induced enzymes in Enterobacteriaceae. Archives of Microbiology 136, 131-136.

PeCher, A., Zinoni, F. \& Bock, A. (1985). The seleno-polypeptide of formic dehydrogenase (formate hydrogen-lyase linked) from Escherichia coli: genetic analysis. Archives of Microbiology 141, 359-363.

Pommier, J., Mandrand, M.-A., Holt, S. E., Boxer, D. H. \& GioRDANo, G. (1992). A second phenazine methosulphate-linked formate dehydrogenase isoenzyme in Escherichia coli. Biochimica et Biophysica Acta 1107, 305-313.

Pope, N. R. \& Cole, J. A. (1982). Generation of a membrane potential by one of two independent pathways for nitrite reduction by Escherichia coli. Journal of General Microbiology 128, 319-322.

Pope, N. R. \& Cole, J. A. (1984). Pyruvate and ethanol as electron donors for nitrite reduction by Escherichia coli K12. Journal of General Microbiology 130, 1279-1284.

RAMSEIER, T. M., WiNTEleR, H. V. \& HeNNeCKe, H. (1991). Discovery and sequence analysis of bacterial genes involved in the biogenesis of c-type cytochromes. Journal of Biological Chemistry 266, 7793-7803.

Rossmann, R., Sawers, G. \& Bock, A. (1991). Mechanism of regulation of the formate-hydrogenlyase pathway by oxygen, nitrate and $\mathrm{pH}$ : definition of the formate regulon. Molecular Microbiology 5, 2807-2814.

Sawers, G., Heider, J., Zehelein, E. \& BoCK, A. (1991). Expression and operon structure of the sel genes of Escherichia coli and identification of a third selenium-containing formate dehydrogenase isoenzyme. Journal of Bacteriology 173, 4983-4993.

StOKER, N. G., FaIRWEather, N. F. \& Spratt, B. G. (1982). Versatile low-copy-number plasmid vectors for cloning in Escherichia coli. Gene 18, 335-341. 